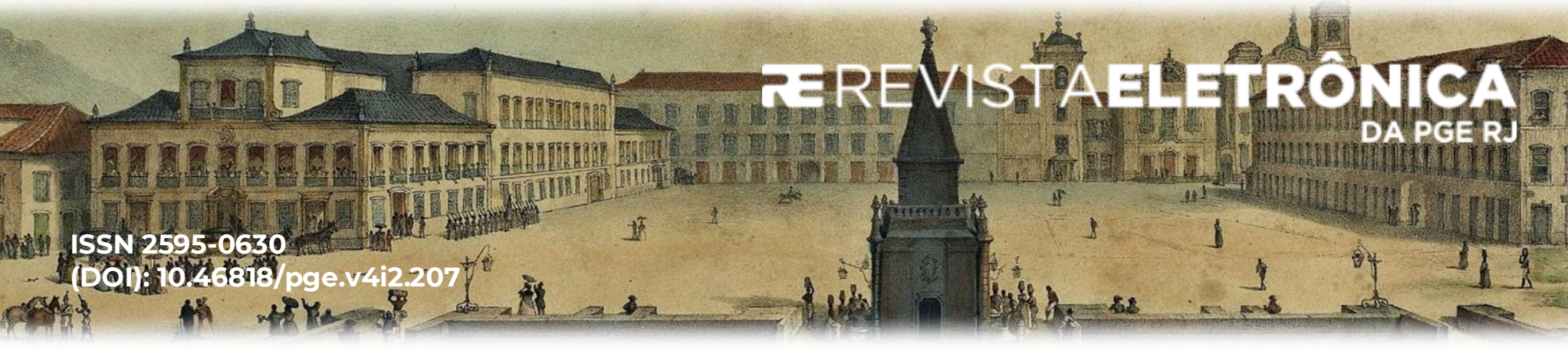

\title{
CONTROLE DE RESULTADOS DA ADMINISTRAÇÃO APLICADO À SEGURANÇA PÚBLICA
}

\author{
ADMINISTRATION RESULTS CONTROL \\ APPLIED TO PUBLIC SECURITY
}

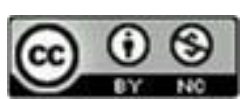

Luis Fernando de França Romão ${ }^{1}$

RESUMO: O presente texto tece algumas considerações doutrinárias sobre o controle de resultados da Administração Pública e as implicações subjacentes quando aplicado à segurança pública, com especial atenção para a realidade do Rio de Janeiro. São abordadas, através de método analítico empírico, três experiências da Administração Pública do Estado do Rio de Janeiro, em governos distintos, para o controle de resultados e eficiência na segurança pública estadual. O estudo caracteriza-se metodologicamente como fenomenológico, tendo por categoria de análise o controle de resultados e por unidade de observação o campo temático da segurança pública, delimitado espacialmente ao Estado do Rio de Janeiro no lapso temporal de três governos distintos. Conclui-se declinando, sob o ponto de vista teórico-prático, as dificuldades e os desafios a envolver o controle das polícias e as políticas públicas de segurança, a partir da realidade do Rio de Janeiro, conquanto a permitir e a fomentar reflexões sobre a problemática extensível à realidade nacional, tendo em vista ser um tema de assaz pertinência e interesse das Administrações Públicas dos Estados Federados e, neste cenário, a assessoria jurídica governamental cumpre função importante para a adequação de constitucionalidade e de juridicidade da conformação da atuação administrativa no que se refere ao controle de resultados das atividades de segurança pública empreendidas pelas instituições policiais civil e militar.

Palavras-Chave: Administração Pública. Controle de Resultados. Segurança Pública.

ABSTRACT: The present text weaves some doctrinal considerations about the control of results of the Public Administration and the underlying implications when applied to public security, with special attention to the reality of Rio de Janeiro. Through empirical analytical methods, three experiences of the Public Administration of the State of Rio de Janeiro, in different governments, for the control of results and efficiency in state public security are approached. The study is methodologically characterized as phenomenological, with the control of results as the category of analysis and the thematic field of public security per unit of observation, spatially delimited to the State of Rio de Janeiro in the time span of three different governments. It concludes by indicating, from a theoretical and practical point of view, the difficulties and challenges involving the control of the police and public security policies, based on the reality of Rio de Janeiro, while allowing and encouraging reflections on the a problem that can be extended to the national reality, in view of being a topic of great relevance and interest of the Public Administrations of the Federated States and, in this scenario, the governmental legal advisory service plays an important role in the adequacy constitutionality and legality of the conformation of administratives actions with regard to the control of results of the public

\footnotetext{
${ }^{1}$ Doutorando em Ciências Jurídico-Políticas pela Faculdade de Direito da Universidade de Lisboa (Portugal). Mestre em Direito do Estado (USP). Pós-graduado em Ciências Criminais e Segurança Pública (UERJ). Bacharel em Direito (PUC-Rio). Advogado.
} 
security activities undertaken by the civil and military police institutions.

KeYwords: Public Administration. Public Security. Results Control.

SUMÁRIO: Introdução. 1. Colocação temática: a Administração Pública voltada para os resultados. 2. A necessidade de se buscar eficiência e resultados para o problema da segurança pública e suas dificuldades. 3. Três experiências da Administração Pública do Estado do Rio de Janeiro no exercício do controle de resultados na área da segurança: 3.1. Gratificação faroeste e os atos de bravura como standard para aferição da eficiência policial. 3.2. Gratificação aos policiais cujas organizações apresentassem redução de indicadores de criminalidade ou padrões de eficiência operacional ou administrativa. 3.3. Sistema de Definição e Gerenciamento de Metas para os indicadores estratégicos de criminalidade do Estado do Rio de Janeiro. 4. Conclusão. Referências.

SUMMARY: Introduction. 1. Thematic placement: Public Administration focused on results. 2 . The need to seek efficiency and results for the problem of public security and its difficulties. 3 . Three experiences of the Public Administration of the State of Rio de Janeiro in the exercise of results control in the area of security: 3.1. Western gratification and acts of bravery as a standard for gauging police efficiency. 3.2. Gratification to police officers whose organizations showed a reduction in crime indicators or operational or administrative efficiency standards. 3.3. System for Defining and Managing Goals for the strategic indicators of crime in the State of Rio de Janeiro. 4. Conclusion. References.

\section{Introdução}

O controle de resultados ainda precisa ser aprofundado no Direito brasileiro, dado os questionamentos existentes sobre o tema, tais como: seria esta modalidade de controle juridicamente exigível? Qual(is) consequência(s) jurídica(s) prevista(s) para o não alcance dos resultados? Se não há responsabilização jurídica do agente público que não alcança os resultados ou, ainda, não há controle judicial sobre os resultados, o que se verifica, na verdade, é um controle meramente formal.

Além disso, a consequência de premiação de um determinado número (reduzido) de agentes públicos pode ser considerada efetivamente como consequência de um controle institucionalizado sobre a Administração Pública? Seria o controle de resultados apenas uma face de outros controles (formal, social) ou deles se distingue?

As dificuldades quanto ao tema prosseguem: quais parâmetros seriam adotados para aferição dos bons e dos maus resultados? Igualmente problemático é como articular o controle de resultados com outros controles sem haver sobreposição e não transformar o controle de resultados pelo resultado ("os fins justificam os meios"), mas o resultado pelo processo (controle dos processos e dos meios conjugados com os resultados). 
Não obstante esses aspectos problemáticos envolvendo o tema de controle de resultados da Administração Pública, quando se aplica tal modalidade a um setor, a questão se robustece e fica mais nítida a problemática, sobretudo quando o setor em análise é a segurança pública, talvez um dos maiores desafios de governança no Brasil.

De modo geral, é noticiado que a segurança pública tem apresentado resultados trágicos, seja pelos altos índices de mortes, seja pelo custo social e financeiro que os problemas na segurança geram para o Estado, para a sociedade e para o setor privado. O Estado se vê obrigado a cada vez mais investir em recursos humanos e aparelhamento para enfrentar o problema da segurança, os cidadãos que convivem com a violência são levados a mudança de hábitos, muitas vezes impondo a si restrições, bem como o setor privado, ante a situação da segurança pública, investe cada vez mais na segurança privada/corporativa (vigilância patrimonial, transporte de valores, segurança pessoal privada, escolta armada).

Essa problemática demanda a necessidade de soluções institucionalizadas e de aprimoramento de resultados em escala suficiente para alteração da realidade. O caminho para a mudança dessa trágica realidade é o desenvolvimento de políticas públicas especializadas, isto é, não bastam políticas sociais genéricas que somente, e supostamente, por via reflexa, trariam benefícios para a segurança pública, por atuarem em algumas causas da violência, tais como educação, trabalho e emprego, assistência social; o investimento nessas áreas é fundamental e constitucionalmente determinado, mas deve haver políticas públicas cujo foco seja a segurança pública e, por conseguinte, esteja articulada suficientemente no seu desenvolvimento com essas áreas sociais, atuando, dessa maneira, no campo preventivo.

Uma premissa básica, isto é, o ponto de partida nesta reflexão, é a consideração da segurança pública como um serviço público prestado pelo Estado-Administração, conquanto em um serviço prestado pelo Estado não se legitimam atuações de combate/guerra, em que haveria inimigos a serem eliminados, naturalização ou normalização de mortes de pessoas, seja de criminosos ou de policiais, nem atuações corporativas isentas de controle, estendendo, desse modo, às instituições policiais um modelo de governança que se fundamenta na eficiência da prestação de serviço público aos cidadãos, notadamente a redução da criminalidade e da violência, compreendido como fundamental para a Justiça Criminal, em que o uso comedido da força, quando necessário, opera dentro da razoabilidade e da proporcionalidade de um Estado de Direito.

Além disso, a compreensão da segurança pública como serviço público permite uma melhor configuração dos controles (internos e externos, em suas diversas denominações, 
modalidades e tipos) sobre a Administração Pública na sua respectiva prestação, a fim de apresentar resultados que preservem a ordem pública democrática com respeito aos direitos fundamentais.

Decerto que este artigo não comporta analisar, com profundidade, todos esses aspectos do problema envolvendo segurança pública e o controle de resultados, mas a título de colocação temática é possível sistematizar essas dificuldades e compartilhar alguns apontamentos sobre o tema, tendo em vista a pouca produção científica nesta área.

Dessa forma, o presente estudo tratará desses aspectos problemáticos envolvendo o controle de resultados e a segurança pública e, em seguida, abordará essa questão da eficiência aplicada à experiência do Rio de Janeiro, por suas orientações díspares ao longo dos últimos anos em busca de melhores resultados, a partir do Decreto $\mathrm{n}^{\circ}$ 21.753/1995 (ato normativo editado sem motivação), pelo Governador Marcello Alencar que instituiu a premiação em pecúnia, por mérito especial, tendo por destinatários policiais civis e militares e bombeiros militares, concedida em caráter individual após o devido reconhecimento e declaração oficial, por meio de gratificação de no mínimo $50 \%$ e no máximo de $150 \%$ dos vencimentos do servidor premiado, conhecida como "gratificação faroeste" e que em razão de seus efeitos e repercussão política negativa foi objeto de sucessivas revogações. ${ }^{2}$

Após essa experiência, foi emitido o Decreto $\mathrm{n}^{\circ}$ 25.641/1999 que dispôs sobre a concessão de gratificação de policiais civis e militares integrantes das organizações policiais que apresentassem redução de indicadores de criminalidade ou padrões de eficiência operacional ou administrativa. A referida gratificação tinha valor máximo de $\mathrm{R} \$ 500,00$ para todos os beneficiários e não se incorporava aos vencimentos, ao contrário da gratificação anteriormente disciplinada.

Será analisado o último modelo jurídico-administrativo estruturado de controle de resultados implantado pelo Decreto $n^{\circ}$ 41.931/2009, editado pelo Governador Sérgio Cabral, que instituiu o Sistema Integrado de Metas e Acompanhamento de Resultados (SIM) da Secretaria de Estado de Segurança.

Objetiva-se sistematizar o tema do controle de resultados da Administração Pública, com suas problemáticas e controvérsias jurídicas, aplicado à segurança pública, que tem sido um dos maiores problemas em todas as capitais do Brasil, contribuindo com apontamentos que possam subsidiar futuras abordagens e desenvolvimento de estudos jurídicos específicos nesta

\footnotetext{
${ }^{2}$ Lei estadual no 2.993/1998 e Decreto no 25.641/1999 - revogação tácita - e Decreto no 26.249/2000 - revogação expressa pelo Governador Anthony Garotinho, sucessor de Marcello Alencar.
} 
área jurídico-administrativa.

O presente texto caracteriza-se metodologicamente como fenomenológico, tendo por categoria de análise o controle de resultados e por unidade de observação o campo temático da segurança pública, delimitado espacialmente ao Estado do Rio de Janeiro no lapso temporal de três governos distintos. Não se dispensa pormenorizado tratamento dogmático da categoria jurídica da eficiência, esta apenas empregada de forma reflexiva e tão somente na sua pertinência e conjugação com o âmbito prático-policial da segurança pública na sua flexão quanto aos resultados.

Busca-se declinar, sob o ponto de vista teórico-prático, as dificuldades e os desafios a envolver o controle das polícias e as políticas públicas de segurança, a partir da realidade do Rio de Janeiro, conquanto a permitir e a fomentar reflexões sobre a problemática extensível à realidade nacional, tendo em vista ser um tema de assaz pertinência e interesse das Administrações Públicas dos Estados Federados e, neste cenário, a assessoria jurídica governamental cumpre função importante para a adequação de constitucionalidade e de juridicidade da conformação da atuação administrativa no que se refere ao controle de resultados das atividades de segurança pública empreendidas pelas instituições policiais civil e militar.

\section{Colocação temática: a Administração Pública voltada para os resultados}

A noção de controle da Administração Pública possui um caráter multifário, segundo Odete Medauar, o que traz dificuldades para a fixação de seu conceito. Em linhas gerais, são acepções ao termo controle: dominação, direção, limitação, vigilância ou fiscalização, verificação e registro, e, na maioria dos casos, o controle é exercido a posteriori ao agir da Administração. A referida autora, propondo uma conceituação para o controle incidente sobre a Administração Pública, apresenta duas acepções: uma em sentido restrito ou técnico-jurídico e outra em sentido amplo. ${ }^{3}$

Em sentido restrito destaca que o controle é a verificação da conformidade da atuação da Administração Pública a um cânone, possibilitando, pois, ao agente controlador a adoção de medida ou proposta em decorrência do juízo formado. Já o controle em acepção

\footnotetext{
${ }^{3}$ MEDAUAR, Odete. Controle da administração pública. 3. ed. São Paulo: RT, 2014, p. 21-33.
} 
ampla significa a verificação da conformidade da atuação da Administração a certos parâmetros, independentemente de ser adotada, pelo controlador, medida que afete juridicamente a decisão ou o agente. ${ }^{4}$

O controle de resultados é uma das expressões do princípio da eficiência, de forma que o dever do bom resultado na atividade administrativa pública tem fundamento constitucional e a falta a esse dever, como afirmara Diogo de Figueiredo Moreira Neto, pode implicar improbidade administrativa, pois há um dever de eficiência e um dever de bom resultado para o administrador público. ${ }^{5}$

Ressaltara o mesmo autor que houve uma evolução do controle, desde os instrumentos da ação, quando se ocupava dos atos e procedimentos da Administração Pública, para a substância da ação, importando, pois, os resultados efetivamente por ela alcançados. Isso leva em conta que os agentes políticos e administrativos, segundo Diogo de Figueiredo, "insistem em proclamar com destaque os acertos de suas intenções para encobrir os desacertos e a miséria dos resultados de suas ações". 6

Observa Floriano de Azevedo Marques Neto ser desafiador tratar de controle em ambiente de desmandos administrativos, escândalos e mecanismos de controle meramente formais e custosos, de modo que deve ser meta a estruturação de um sistema de controle eficiente, a permitir aferir o quanto a atividade administrativa está a reverter em benefício do administrado. Assim, o controle da Administração Pública transcende em muito, segundo o autor, o debate em torno de controle interno e/ou externo, bem como das competências dos Tribunais de Contas, pois o controle não se presta só para evitar desvios de bens ou recursos públicos, vai além, controla o adequado uso do poder e o resultado do seu manejo. ${ }^{7}$

Deste modo, o controle não é um fim em si mesmo, mas instrumento para aperfeiçoamento da Administração Pública em busca da eficiência e da efetividade, segundo Floriano Marques Neto, e a Administração só será boa se aliar lisura e economicidade com eficiência, e, por conseguinte, o controle será bom se for capaz de aferir os resultados das políticas públicas. ${ }^{8}$

\footnotetext{
${ }^{4}$ Ibid., p. 32.

${ }^{5}$ MOREIRA NETO, Diogo de Figueiredo. Novo referencial no Direito Administrativo: do controle da vontade ao do resultado: a juridicização dos resultados na Administração Pública. Fórum Administrativo - Direito Público FA, Belo Horizonte, ano 6, n. 67, set. 2006.

${ }^{6}$ Loc. cit.

${ }^{7}$ MARQUES NETO, Floriano de Azevedo. Os grandes desafios do controle da Administração Pública. Fórum de Contratação e Gestão Pública - FCGP, Belo Horizonte, ano 9, n. 100, abr. 2010.

${ }^{8}$ Loc. cit.
} 
Por tais razões, de acordo com o referido administrativista, o controle não pode ser meramente formal, voltado mais para o processo e à verificação do cumprimento de prescrições em detrimento da análise de impacto das medidas adotadas e, por conseguinte, da efetividade dos resultados e critica que a defesa da moralidade e do patrimônio público - valores relevantes, inegavelmente - passou a ser objetivo bastante e suficiente, sendo a única meta evitar-se o descalabro administrativo, ainda que ao custo da inoperância da Administração Pública. ${ }^{9}$

Tratar de controle de resultados na Administração Pública é concretizar o mandamento constitucional da eficiência às ações do Poder Público. Embora o tema seja relativamente novo, tem raízes no chamado controle de eficiência a que Caio Tácito já fizera referência desde o final da década de 1960 no Direito brasileiro, ao mencionar, à época, que o Estado, ao assumir a prestação direta de serviços de teor econômico ou assistencial, o interesse “e mesmo a sobrevivência de grande número de indivíduos" passava a depender da eficiência da Administração e não apenas de sua legalidade. ${ }^{10}$

Sem levar em consideração que possivelmente o maior peso dado à eficiência do que à legalidade no final da década de 1960 pudesse ser consequência do regime militar e a produção de atos administrativos autoritários, Caio Tácito passou a aludir ao duplo aspecto do controle a ser exercido sobre a Administração Pública, em que de um lado estaria o controle de legalidade, buscando a preservação dos direitos dos administrados e do patrimônio público e, de outro lado, o controle de eficiência, objetivando o aperfeiçoamento das instituições administrativas, cuidando da sua melhor produtividade. ${ }^{11}$

Ademais, convém mencionar que na doutrina italiana houve o desenvolvimento do chamado controle de gestão, desde as reformas de 1993, de modo que o modelo italiano abrangia eficiência, eficácia e economicidade, fazendo referência à Administração de resultados e para resultados, como se pode verificar dos estudos de Lucio Iannotta, ao considerar estas referências como fórmulas de origem doutrinária fruto de leitura sistemática e unificante da pluralidade de textos legislativos que, direta ou indiretamente, referiam-se ao(s) resultado(s). Assim, segundo o referido jurista italiano, a "Administração de resultado é, portanto, construção doutrinária". ${ }^{12}$

\footnotetext{
${ }^{9}$ Loc. cit.

${ }^{10}$ TÁCITO, Caio. O controle da Administração e a nova Constituição do Brasil. Revista de Direito Administrativo, Rio de Janeiro, v. 90, 1967, p. 24.

${ }^{11}$ MEDAUAR, Odete. Op. cit., p. 41.

${ }^{12}$ IANNOTTA, Lucio. Merito, discrezionalità e risultato nelle decisioni amministrative (l'arte di amministrare). Diritto processuale amministrativo, v. 23, fasc. 1, p. 1-51, 2005, p. 1.
} 
O mesmo doutrinador italiano salienta ainda que o modelo jurídico de Administração dos resultados, de resultado, para resultados, é marcado pelo dever de conseguir - com celeridade, com o uso diligente e acurado dos recursos, com pleno conhecimento dos fatos e do contexto, e com transparência - resultados concretos tecnicamente válidos, correspondentes ao fim determinado pela lei e pelos objetivos fixados pelos órgãos de governo da Administração, objetivos estes que devem satisfazer o direito e a liberdade das pessoas, a formação social e da comunidade administrada com a sua participação. ${ }^{13}$

Com efeito, Lucio Iannotta destaca que a juridicização do resultado administrativo constitui um evento não só novo, mas fortemente inovador, até mesmo revolucionário, porque impõe a todo sujeito que participa da função administrativa - dever jurídico - de ter em consideração, antecipadamente, em cada decisão e em relação a cada comportamento, não só da situação existente, mas da sua futura modificação, a fim de alcançar determinados objetivos programados para satisfação do interesse público. ${ }^{14}$

Uma observação significativa para o setor de segurança pública, especialmente quanto às três experiências de controle de resultados da Administração Pública do Estado do Rio de Janeiro infra apresentados, é salientada por Odete Medauar ao enfatizar que a Administração atua pela atividade das pessoas e, por consequência, o controle sobre atos ou atividades traz subjacente a fiscalização das pessoas. ${ }^{15}$

Por estas razões que o controle de resultados geralmente tem sido reduzido a premiações ou bonificações salariais de determinados números de agentes que alcançam metas traçadas pelos órgãos de governo, o que acaba por tornar esse tipo de controle fraco e de alcance limitado frente ao universo da Administração Pública, ficando reduzido a um programa de premiação com caráter muito mais de incentivo/motivação funcional do que de análise de conformidade da produção da Administração Pública a determinados parâmetros de eficiência.

O sucesso ou insucesso de um controle de resultados visando a atuação administrativa eficiente não está somente no resultado produzido, mas desde o processo inicial de planejamento, elaboração e fixação das metas e objetivos que os agentes públicos irão perseguir para satisfação do interesse público.

\footnotetext{
13 Ibid., p. 8.

${ }^{14}$ Ibid., p. 15-16.

${ }^{15}$ MEDAUAR, Odete. Op. cit., p. 48.
} 


\section{A necessidade de se buscar eficiência e resultados para o problema da segurança pública e suas dificuldades}

No âmbito da segurança pública a eficiência foi requerida pelo constituinte desde a promulgação da Constituição em 1988, pois antes mesmo de se constitucionalizar tal princípio como disposição geral para a atuação da Administração Pública de qualquer dos Poderes da União, Estados e Municípios no artigo 37, através da Emenda Constitucional nº 19/1998, a previsão de eficiência já estava constitucionalizada no $\S 7^{\circ}$ do artigo 144 , por isso afirma-se que o padrão de eficiência do serviço de segurança pública decorre tanto do princípio geral da Administração quanto do princípio específico do mencionado dispositivo. ${ }^{16}$

Com base nesse suporte constitucional, Valter Foleto Santin, mesmo considerando a margem de discricionariedade da Administração na atuação na segurança pública, entende ser cabível o seu controle, inclusive judicial, podendo ser sindicadas a eficiência, a regularidade e a adequação do serviço de prevenção criminal. ${ }^{17}$

Além disso, o referido autor, tratando da adequação do serviço de segurança pública, faz uma leitura a partir das condições que caracterizam um serviço público como adequado à luz do artigo $6^{\circ}, \S 1^{\circ}$ da Lei $n^{\circ} 8.987 / 1995$, que dispõe sobre o regime de concessão e permissão da prestação de serviços públicos previsto no artigo 175 da Constituição. Dessa maneira, Valter Foleto Santin analisa a segurança pública a partir dos seguintes requisitos: regularidade, continuidade, eficiência, segurança, atualidade, generalidade, cortesia na sua prestação e remuneração.

O serviço de segurança pública atende ao requisito da regularidade porque prestado com regularidade de tempo, com repetições constantes; em geral atende ao requisito da continuidade, pois é prestado de forma sequencial e sem interrupção; não atende à condição de eficiência - que se refere ao melhor atendimento possível, de acordo com um padrão de qualidade - porque os índices de criminalidade e a sensação de insegurança da população são elevados; também não atende à condição de segurança porque o serviço de segurança pública é atividade perigosa e não consegue reduzir os riscos dos usuários, tendo em vista os altos índices de criminalidade e violência. ${ }^{18}$

\footnotetext{
${ }^{16}$ SANTIN, Valter Foleto. Controle judicial da segurança pública: eficiência do serviço na prevenção e repressão ao crime. 2. ed. São Paulo: Verbatim, 2013, p. 49.

${ }^{17}$ Ibid., p. 70.

${ }^{18}$ Ibid., p. 101.
} 
Igualmente, tal serviço não atende ao requisito da atualidade em razão das técnicas, equipamentos e instalações destinados à prestação da segurança púbica não corresponderem à tecnologia mais atual à disposição da segurança em geral, especialmente quando se verifica que a segurança privada dispõe de recursos tecnológicos avançados e modernos equipamentos; o serviço de segurança pública atende em parte ao requisito da generalidade, pois prestado à população em geral, embora seja um serviço insuficiente para atender a demanda populacional com policiamento em determinados bairros e cidades. ${ }^{19}$

Por conseguinte, o serviço de segurança, segundo o mencionado autor, atenderia em parte ao requisito de cortesia, porque a excessiva demora no atendimento e o contato às vezes não amistoso entre policiais e cidadãos impacta na imagem da instituição policial; por fim, quanto à remuneração do serviço, ressalta que deve ser mantido pelos impostos, por sua condição de prestação geral indivisível, sendo inviável a cobrança de taxa por serviço de segurança pública, conforme já decidido pelo Supremo Tribunal Federal. ${ }^{20-21}$

No plano teórico-doutrinário a análise é perfeitamente apreensível e se coaduna com os objetivos jurídico-constitucionais e administrativos, porém a prática da segurança pública tem revelado que não é tão simples buscar os resultados compatíveis com o modelo abstratamente previsto na Constituição da República de 1988. A segurança pública no Rio de Janeiro, por exemplo, é, há décadas, a "própria crise como rotina" ${ }^{22}$, convindo acentuar alguns elementos da sua dinâmica: i) armas de guerra, com alto poder de destruição, na posse de traficantes para se defesa contra os inimigos de outras facções e enfrentamento com a polícia ${ }^{23}$; ii) confrontos de alta letalidade ${ }^{24}$; iii) instituições policiais há anos tomadas por uma corrupção sistêmica, alimentando o ciclo de violência ${ }^{25}$; iv) policiais atuando no limite, em ambientes hostis, internos e externos, sem condições de servirem à população enquanto agentes

\footnotetext{
${ }^{19}$ Loc. cit.

${ }^{20}$ Ibid., p. 101-102.

${ }^{21}$ STF, Plenário, ADI 1942-MC/PA, Rel. Min. Moreira Alves, j. 05.05.1999, DJ 22.10.1999.

22 BELTRAME, José Mariano. Todo dia é segunda-feira. Rio de Janeiro: Sextante, 2014, p. 75 e 89.

${ }^{23}$ STORANI, Paulo. Vitória sobre a morte: a glória prometida. O "rito de passagem" na construção da identidade dos Operações Especiais. Dissertação (Mestrado em Antropologia Social), Programa de Pós-Graduação em Antropologia, Universidade Federal Fluminense. Niterói, 2008.

${ }^{24}$ Paulo Storani analisa a evolução da violência dos confrontos armados na ótica da Polícia Militar do Rio de Janeiro a partir de cinco fases de confronto policial: 1 - Romântica (1950/1960); 2 - Repressão (1970); 3 - Difusão do tráfico (1980); 4 - Beligerante (1990); 5 - Guerra Urbana (1ª́cada do século XXI).

${ }^{25}$ HOLlANDA, Cristina Buarque de. Polícia e direitos humanos: política de segurança pública no primeiro governo Brizola (Rio de Janeiro: 1983-1986). Rio de Janeiro: Revan, 2005, p. 126.
} 
prestadores de um serviço público ${ }^{26-27-28}$; v) a cobertura da mídia pauta as intervenções dos órgãos policiais, comprometendo um planejamento mais abrangente e equânime ${ }^{29}$; vi) $O$ elemento político-eleitoral vincula à sua dinâmica as ações de segurança. ${ }^{30}$

Esses aspectos da realidade do Rio de Janeiro, que em diferentes graus podem se aproximar em alguma medida de outras localidades do Brasil, servem para demonstrar que "no campo da segurança pública, tudo é muito mais complicado do que parece". ${ }^{31}$ Ademais, em um setor em que a crise é a rotina, com inúmeros problemas de gestão de seus servidores (pois na prática as instituições policiais dividem-se em oficiais e praças, delegados e não-delegados) que não se percebe como prestadora de um serviço público, com dificuldades de se estabelecer organização administrativa e processos decisórios que sejam funcionais para garantir a ordem pública e a incolumidade das pessoas e do patrimônio, tratar de controle de resultados é um enorme desafio.

Não se pode permitir que sob a justificativa de eficiência na prestação da segurança pública haja abusos dos órgãos policiais, isto é, aumente-se o poder de repressão e, por conseguinte, a brutalidade policial, como se deu no caso da polícia de Nova York com a "tolerância zero" 32 . Contra isto, Valter Foleto Santin menciona a necessidade de se aumentar na mesma proporção do poder de atuação policial o controle da atividade por mecanismos

\footnotetext{
26 "[Claudio Ferraz, delegado de Polícia, à época titular da Delegacia de Repressão às Ações Criminosas Organizadas e Inquéritos Especiais - DRACO-IE] desfaz qualquer ilusão de que o policial brasileiro está na profissão para dar conforto ao cidadão. 'Ele não tem a mínima condição de ser simpático, agradável ou cortês. Ele está cheio de ódio. Ele é uma bomba-relógio"'. CARVALHO, Luiz Maklouf. Crime \& Castigo. O caçador de milícias. PIAUÍ, 27. ed., dez. 2008. Disponível em: <https://piaui.folha.uol.com.br/materia/o-cacador-demilicias/>. Acesso em: 08 mar. 2021.

${ }^{27}$ Em sentido próximo, mas a partir da visão do policial militar, Paulo Storani destaca que os policiais lidam com situações que normalmente causariam repugnância, medo ou paralisia em outros e a prática da rua orienta a visão militar de combate ao crime e ao ethos guerreiro - o policial operacional pronto para o confronto com criminosos armados. STORANI, Paulo. Op. cit., p. 33-34.

${ }^{28}$ Com isso, infere-se que policiais civis e militares não podem ser reduzidos a simples categorias do funcionalismo público comum, pois a natureza de suas funções e a prática de suas atividades não se assemelham às outras categorias do serviço público, de modo que isso repercute ao se analisar o controle de resultados na segurança pública.

${ }^{29}$ PÉREZ, Elizabeth Martin. Meios de comunicação de massa e aparato policial: a ação da mídia em questões de segurança pública. Dissertação (Mestrado em Administração Pública) Escola Brasileira de Administração Pública e de Empresas, Fundação Getúlio Vargas. Rio de Janeiro, 2003.

${ }^{30}$ As políticas públicas de segurança no Rio de Janeiro tendem a sofrer influência eleitoral e são capazes de exercer peso político decisivo nas eleições, como se verifica das experiências desde o processo eleitoral de 1982 até os mais recentes, em que a segurança pública e a violência tornaram-se variáveis eleitorais decisivas. ROMÃO, Luis Fernando de França. Sobre a proteção jurídica das políticas públicas do processo eleitoral: o caso da política de segurança pública no Estado do Rio de Janeiro. In: MENDES, Soraia Rosa; AGUIAR, Julio Cesar de (Orgs.). Segurança pública. Brasília: IDP, 2014, p. 127-152.

${ }^{31}$ SOARES, Luiz Eduardo. O enigma de Nova York. In: OLIVEIRA, Nilson Vieira (Org.). Insegurança pública: reflexões sobre a criminalidade e a violência urbana. São Paulo: Nova Alexandria, 2002, p. 229.

${ }^{32}$ SOARES, Luiz Eduardo. O enigma de Nova York. In: OLIVEIRA, Nilson Vieira (Org.). Op. cit., p. 227-228.
} 
internos e externos para "adaptação aos anseios populares e diminuição dos riscos de abusos e excessos policiais". 33

É recorrente a lógica de se apresentar como resultados da atuação da Administração Pública na segurança pública números de atividades e operações, como se estes fossem critérios suficientes para aferição da eficiência das instituições policiais. Apresentam-se números de prisões e apreensões de drogas e armas "como se bastassem as ações policiais; como se elas fossem um fim em si", acentua Luiz Eduardo Soares, observando, ainda, que "a lista de operações apenas demonstra que as corporações se esforçaram, e nada diz a propósito da eficiência, eficácia e efetividade do que se fez". ${ }^{34}$ Até porque é sabido que "se a droga é apreendida, o bandido compra mais. Se ele vai preso, em segundos já tem um substituto" ${ }^{35}$, de modo que esse não é um parâmetro válido suficientemente para o exercício de um controle de resultados sobre a Administração Pública.

Por conseguinte, outro caminho proposto seria definir a eficiência da prevenção pelos índices de criminalidade "numa comparação periódica, anual preferencialmente, para aferição do nível dos serviços e padrão de eficiência", com "publicação de índices de criminalidade, tipos de delitos, locais de maior criminalidade, providências tomadas e a serem tomadas". 36

Ocorre que esse parâmetro também não é seguro. Não há, segundo Luiz Eduardo Soares, uma ligação simples e óbvia entre a melhoria dos serviços de segurança pública e a quantidade de crimes em um mesmo território, podendo, sim, haver ligação, mas não será simples e incontroversa, pois a quantidade de crimes pode diminuir porque as condições externas às dinâmicas criminais que condicionam sua existência desapareceram e são substituídas por outras, desfavoráveis à sua prática, sem que, portanto, a política de segurança ou o comportamento dos órgãos policiais contribuam de qualquer modo para isso, ou seja, sem um atuar positivo e decisivo da Administração Pública no setor da segurança. ${ }^{37}$

Da mesma forma, a quantidade de crimes também pode decrescer porque algumas condições internas às dinâmicas criminais se transformam sem que haja mudanças na qualidade da política de segurança ou melhorias na qualidade do desempenho policial, segundo Luiz

\footnotetext{
${ }^{33}$ SANTIN, Valter Foleto. Op. cit., p. 55.

${ }^{34}$ SOARES, Luiz Eduardo. Legalidade libertária. Rio de Janeiro: Lumen Juris, 2006, p. 339.

${ }^{35}$ BELTRAME, José Mariano. Op. cit., p. 81.

${ }^{36}$ SANTIN, Valter Foleto. Op. cit., p. 103-104.

${ }^{37}$ SOARES, Luiz Eduardo. O enigma de Nova York. In: OLIVEIRA, Nilson Vieira (Org.). Op. cit., p. 229.
} 
Eduardo Soares ${ }^{38}$, salientando o autor que até mesmo o indicador mais óbvio, o número de crimes praticados, deixa de sê-lo quando se evoca a subjetividade da percepção da violência, isto é, da sensação de insegurança: “o que é pior: o risco de vitimização, calculado com base no número de ocorrências e na distribuição espacial, temporal e social de probabilidades, ou a sensação de insegurança?", pontuando que “estatísticas não curam o medo”, porém, "a presença da polícia pode ser um remédio eficaz, mesmo que não altere a margem de risco, segundo o cálculo de probabilidade". ${ }^{39}$

Até mesmo os dados e as estatísticas, que funcionariam como um indicador variável sobre os resultados da Administração Pública na área da segurança, não podem ser considerados como parâmetro absolutamente seguro para o controle, pois além de serem manipuláveis por questões políticas, dependem dos policiais, isto é, a "realidade" estatística é forjada "a depender da atitude dos dirigentes máximos da polícia”, segundo Jorge da Silva:

Se este ou aquele secretário de Polícia (ou de Segurança) entende que o trabalho da polícia deve ser medido pelo número de ocorrências atendidas, saem os delegados e os comandantes de Unidades da PM à cata do registro de qualquer tipo de ocorrência, desde o furto de galinha, às discussões de marido e mulher; instala-se aí a era da "produção" de ocorrências. Se, ao contrário, o secretário de Polícia (ou de Segurança) entende que um baixo número de ocorrências registradas é função da eficiência da polícia, passam as delegacias a deixar de registrar as ocorrências, só registrando aquelas que, a critério dos policiais, sejam importantes ou de vulto. Quanto aos comandantes de Unidades da PM, ai daqueles cujos registros apresentarem altos números de ocorrências. Neste caso, incentiva-se a solução informal das situações consideradas "sem importância". Tudo isto a causar a apatia dos policiais, civis e militares, e a incentivar a prevaricação e a corrupção. Conclusão: independentemente dos índices reais de criminalidade, todos saem atendidos: os governos eventuais, os secretários, os delegados e os comandantes, e os policiais. Digna de realce é a capacidade adaptativa dos policiais, de todos os escalões. Só a população não é atendida. Em suma, aumentar ou diminuir a criminalidade (a registrada pela polícia) passa a ser mera questão de decisão pessoal. Basta que se decida registrar ou não as ocorrências. Exceção a esta regra são os homicídios, pois para que eles desaparecessem das estatísticas seria necessário que os cadáveres também desaparecessem. ${ }^{40}$

Eis o desafio de se estabelecer os parâmetros para um controle sério sobre os resultados da atuação da Administração Pública na área da segurança e, por conseguinte, do atendimento ao princípio constitucional da eficiência desse serviço público. Mais fácil do que se aferir um standard para a eficiência policial, seria aferir a ineficiência, como observa Valter Foleto Santin, pois a recepção de um serviço de prevenção de crimes em que a maioria da

\footnotetext{
${ }^{38}$ Ibid., p. 229-230.

${ }^{39}$ Ibid., p. 231.

${ }^{40}$ DA SILVA, Jorge. Controle da criminalidade e segurança pública na nova ordem constitucional. 2. ed. Rio de Janeiro: Forense, 1990, p. 82.
} 
população já foi vítima de delitos e sofre de sensação de insegurança, segundo ele, é visivelmente ineficiente, não funcionando adequadamente, tendo em vista que em situação de “elevada vitimização, vislumbra-se com facilidade que a finalidade estatal não foi atingida; não é eficiente", sendo a insatisfação pública com a qualidade e a quantidade do serviço de segurança pública um "indicador forte de ineficiência, expressado pelo baixo índice de aceitação da polícia pelo povo". ${ }^{41}$

Convém salientar que havendo uma melhoria no serviço policial, aumentando a sua aprovação popular e estabelecendo uma relação de confiança com os cidadãos, haveria redução da subnotificação e se ampliaria "o conhecimento sobre a dinâmica criminal, gerando um círculo virtuoso", segundo Luiz Eduardo Soares, pois com mais informações fornecidas pela população melhor seria o trabalho policial e os resultados das investigações, porém, formar-seia um paradoxo, uma vez que "a melhora dos serviços policiais implica aumento do número de crimes registrados, o que poderia ser lido, equivocadamente, como crescimento da criminalidade". ${ }^{42}$

\section{Três experiências da Administração Pública do Estado do Rio de Janeiro no exercício do controle de resultados na área da segurança}

Não há soluções fáceis para se estruturar um controle de resultados sobre a prestação do serviço de segurança pública pela Administração, nem parâmetro absolutamente seguro que possa aferir a eficiência do serviço policial. Porém, seja pela necessidade de se manter ambiente mínimo de controle ou, especialmente como vem ocorrendo, de se incentivar os policiais a se alinharem à política de segurança traçada pelos órgãos de governo, algumas experiências foram empreendidas pela Administração Pública do Estado do Rio de Janeiro, destacando-se a seguir três delas, desenvolvidas em governos distintos para tentar conter suas crises de governança na segurança.

\subsection{Gratificação faroeste e os atos de bravura como standard para aferição da eficiência policial}

\footnotetext{
${ }^{41}$ SANTIN, Valter Foleto. Op. cit., p. 102.

${ }^{42}$ SOARES, Luiz Eduardo. Legalidade libertária, p. 344.
} 
A partir da primeira gestão do Governador Leonel Brizola, segundo Cristina Buarque de Hollanda, "a política estadual no Rio de Janeiro inaugurou um movimento pendular em que orientações díspares para o setor da segurança pública oscilaram no poder". ${ }^{43}$ Como já analisado em outro estudo ${ }^{44}$, convém mencionar que o candidato Moreira Franco (PMDB) venceu as eleições estaduais em 1986 com a promessa de acabar com a violência no Rio de Janeiro em seis meses, endurecendo o discurso oficial contra o crime e culpando o absenteísmo de Brizola, associado à defesa dos direitos humanos, como responsáveis pelo estado de violência.

Após o governo Moreira Franco (1987-1990), Leonel Brizola voltou a governar o Estado (1991-1994), tendo sido reeleito reafirmando a disposição de eliminar a truculência policial. Porém, por falta de investimentos, essas mudanças não ocorreram e as dificuldades na segurança pública já eram significativamente maiores que a de seu primeiro governo (19831986), pois a violência tinha chegado a proporções de descontrole total com grupos de extermínio atuando, quando ocorreram as chacinas da Candelária e de Vigário Geral em $1993 .{ }^{45}$ O Governo Brizola (PDT) é, então, associado à desordem. Nesse contexto, Marcello Alencar (PSDB) é eleito Governador para a gestão 1995-1998, que volta com a política de endurecimento, da qual a chamada "gratificação faroeste" é o seu símbolo emblemático.

Para dar seguimento à política de repressão, buscando incentivar a atuação dos órgãos policiais nesta perspectiva, foi editado o Decreto $\mathrm{n}^{\circ} 21.753$, de 8 de novembro de 1995 , que concedia "premiação em pecúnia, por Mérito Especial", tendo como destinatários os policiais civis e militares e os bombeiros militares. O prêmio era concedido em caráter individual por ato do Chefe do Poder Executivo e pago por meio da concessão de Gratificação de Encargos Especiais, em percentual mínimo de 50\%, inicialmente ${ }^{46}$, e máximo de $150 \%$ dos vencimentos do servidor premiado. Convém salientar que o referido ato normativo foi emitido com vício, pois não externou qualquer motivação, impossibilitando, com isso, "a visibilidade

\footnotetext{
${ }^{43}$ HOLLANDA, Cristina Buarque. Op. cit., p. 154.

${ }^{44}$ ROMÃO, Luis Fernando de França. Op. cit., p. 138.

${ }^{45}$ Sobre estas chacinas, diz Nilo Batista, Vice-Governador do Estado à época desses crimes: "Sempre que alguém fala comigo sobre as chacinas da Candelária e de Vigário Geral, peço-lhe observar que existem chacinas realizadas contra políticas governamentais de proteção aos direitos humanos (que tanto irritam certos grupos policiais) e existem chacinas que cumprem políticas governamentais de brutalidade e extermínio, como a chamada Chacina do Pan ou as tantas chacinas que antecederam o 'conto' da 'pacificação'". BATISTA, Nilo. Prefácio. In: OLIVEIRA, Siro Darlan de; ROMÃO, Luis Fernando de França. A história da criança por seu conselho de direitos. Rio de Janeiro: Revan, 2015, p. 8.

${ }^{46} \mathrm{O}_{\text {Decreto }} \mathrm{n}^{\mathrm{O}} 23.577$, de 8 de outubro de 1997, alterou o percentual mínimo para $10 \%$ dos vencimentos do servidor premiado.
} 
intencional do ato", como acentuara Diogo de Figueiredo Moreira Neto. ${ }^{47}$ Não obstante tal irregularidade, nenhuma medida foi empreendida para o controle jurisdicional repressivo sobre o referido ato administrativo que produziu seus efeitos jurídicos.

Apesar do nomen juris ser "premiação em pecúnia, por Mérito Especial”, ficou conhecida por "gratificação faroeste", em razão de se premiar os chamados "atos de bravura" dos policiais, estimulando, financeiramente, o confronto, enaltecendo um ambiente de "guerra", de "combate", como se pode vislumbrar pelos termos contidos nas motivações específicas positivadas que se repetem nos mais de oitenta decretos que passaram a conceder ou majorar as gratificações a milhares de profissionais da segurança pública que eram listados abaixo dos incisos contendo as motivações da gratificação de $50 \%$ a $150 \%$ de seus vencimentos. ${ }^{48}$

O efeito dessas concessões da Administração Pública foi o incentivo ao enfrentamento armado e uma desenfreada busca por parte dos profissionais da segurança pública em se beneficiarem dessas gratificações que se incorporavam aos vencimentos e poderiam mais que dobrar a remuneração base do servidor. Se antes o policial buscava complementar a renda oficial com "bico" na segurança privada ou com a corrupção ("acerto"), com a institucionalização da premiação em pecúnia houve um deslocamento de esforço para que todo e qualquer agir fosse recompensado como "Mérito Especial".

\footnotetext{
${ }^{47}$ MOREIRA NETO, Diogo de Figueiredo. Curso de direito administrativo: parte introdutória, parte geral e parte especial. 16. ed. Rio de Janeiro: Forense, 2014, p. 154-155.

48 "Por terem, mesmo numericamente inferiorizados, sustentado intenso tiroteio com perigosos facínoras, que portavam armas de grosso calibre". (Art. $1^{\circ}$, inciso V, Decreto ${ }^{\circ}$ 22.317/1996). "Por terem participado de operação que culminou com a prisão e morte de importantes traficantes de tóxicos, apreendido grande quantidade de substância entorpecente, farto material para endolação, armamento e munição". (Art. $1^{\circ}$, inciso XIX, Decreto n ${ }^{\circ}$ 22.317/1996). "Por ter demonstrado coragem e alto grau de profissionalismo, quando com o risco da própria vida, reagiu a um assalto e mesmo ferido, colocou fora de combate um dos assaltantes". (Art. $1^{\circ}$, inciso V, Decreto ${ }^{\circ}$ 22.317/1996). "Por terem, quando em operação, demonstrado alto grau de profissionalismo, coragem e destemor, trocando tiros e colocando fora de combate marginais da lei, com apreensão de grande quantidade de armamento, munição e uma granada". (Art. $1^{\circ}$, inciso VII, Decreto n 22.561/1996). "Por ter demonstrado alto grau de coragem, abnegação e preparo profissional ao comandar várias operações policiais que resultaram, após troca de tiros, em falecimento e prisão de vários traficantes, com apreensão de grande quantidade de armamento, munições, material tóxico e recuperação de veículos roubados e furtados". (Art. $1^{\circ}$, inciso VIII, Decreto $\mathrm{n}^{\circ}$ 22.561/1996). "Por terem, quando em patrulhamento, se deslocado para o local onde minutos antes havia ocorrido troca de tiros entre quadrilhas rivais, que resultou na morte de dois marginais, e ao efetuarem diligência nas imediações, apreenderam farto material tóxico e um veículo que estava de posse dos traficantes". (Art. $1^{\circ}$, inciso XX, Decreto $\mathrm{n}^{\circ}$ 22.561/1996). "Por ter demonstrado alto grau de profíssionalismo, coragem e destemor, quando em operação, trocou tiros e colocou fora de combate marginais da lei, com apreensão de grande quantidade de armamento, munição e uma granada". (Art. $3^{\circ}$, inciso I, Decreto n ${ }^{\circ}$ 22.561/1996). "Por terem participado de diligência, com troca de tiros, com fulcro de fazer cumprir Mandado de Busca e Apreensão, logrando êxito em colocar fora de combate e prender marginais da lei, tendo uma prisão preventiva decretada, em virtude de haver confessado a prática de dois homicídios". (Art. $3^{\circ}$, inciso VI, Decreto ${ }^{\circ}$ 22.561/1996). "Por ter participado, com troca de tiros, de operação na Favela do Muquiço, em Deodoro, colocando fora de combate perigoso traficante, assaltante de bancos e homicida". (Art. $1^{\circ}$, inciso IV, Decreto $n^{\circ}$ 22.954/1997).
} 
Assim, funções intrínsecas à rotina do serviço policial passaram a ser recompensadas com as Gratificações Especiais como: a elucidação de um caso $^{49}$ ou simples indiciamento $^{50}$; o corriqueiro cumprimento de diligências e de mandados, própria razão de existir da polícia civil, era motivo para compensação ${ }^{51}$ ou, então, a participação em ação policial já ocasionava ato de bravura ${ }^{52}$; o carcereiro, que cumprisse sua função zelando pela manutenção da ordem e impedindo que não houvesse fugas de detentos, também era gratificado ${ }^{53}$; o salvavidas que resgatasse algum banhista do mar $^{54}$ e também o bombeiro que atendesse chamado e impedisse o vazamento de gás ${ }^{55}$ ou que o fogo se alastrasse, igualmente recebia o reconhecimento do Chefe do Poder Executivo pelos méritos dos esforços empreendidos.

Se aplicada a mesma lógica a outros setores da Administração Pública, seria como premiar com gratificação nos vencimentos o professor por lecionar uma aula ou por ter seu aluno aprovado de série, ou, no caso da saúde, condecorar o médico que realiza consulta ou operação, o enfermeiro que aplica o medicamento, quer dizer, premiaram-se ações rotineiras, intrínsecas à dinâmica do serviço público prestado, não havendo nada de extraordinário, apenas exaltação de um atuar que deveria ser ordinário.

\footnotetext{
49 "Por ter demonstrado espírito de iniciativa e profissionalismo, após longo trabalho de investigação para elucidação de $u m$ homicídio, culminando com a descoberta da autoria e a prisão do criminoso" (art. $1^{\circ}$, inciso III, Decreto $^{\circ}$ 22.955/1997). "Por ter, após competente investigação, conseguido elucidar um homicídio e prender o autor do crime" (art. 1" , inciso XIV, Decreto ${ }^{\circ}$ 22.955/1997). "Por terem, após várias diligências, conseguido elucidar um crime, sendo o autor um criminoso de alta periculosidade" (art. $1^{\circ}$, inciso XVIII, Decreto $\mathrm{n}^{\circ}$ 22.955/1997). "Por terem elucidado um crime de homicídio e prendido o autor em flagrante" (art. $1^{\circ}$, inciso XLIV, Decreto $^{\circ}$ 22.973/1997). "Pelos excelentes resultados obtidos ao participarem das investigações que culminaram com a prisão de um estelionatário" (art. $1^{\circ}$, inciso V, Decreto n 24.220/1998).

50 "A concessão de premiação em pecúnia, por Mérito Especial, aos policiais civis que demonstraram responsabilidade, coragem e dedicação no cumprimento do dever funcional, no percentual de $50 \%$ por participarem ativamente nas investigações, objeto de Inquérito Policial instaurado pela Delegacia de Polícia Fazendária, as quais culminaram com a indiciação de vários fiscais de renda, pela prática dos crimes de prevaricação e coação" (art. $1^{\circ}$, Decreto n ${ }^{\circ}$ 23.270/1997).

51 "Por terem se empenhado na realização de várias prisões em flagrante delito, bem como no cumprimento de diversos mandados de prisão" (art. $1^{\circ}$, inciso VI, Decreto n ${ }^{\circ}$ 23.315/1997). "Pelos excelentes resultados obtidos ao cumprirem mandados de prisão, prendendo marginais da lei autores de vários sequestros" (art. $1^{\circ}$, inciso VII, Decreto $\left.\mathrm{n}^{\circ} 23.473 / 1997\right)$.

52 "Por ter demonstrado coragem e determinação ao participar de ação policial, razão pela qual foi promovido por Ato de Bravura" (art. $1^{\circ}$, inciso IX, Decreto no $24.174 / 1998$ ).

53 "Por ter evitado fuga em massa nas dependências carcerárias da POLINTER, demonstrando alto grau de profissionalismo e abnegação" (art. $1^{\circ}$, inciso II, Decreto $n^{\circ}$ 22.955/1997). "Pelo excelente trabalho que têm desenvolvido na seção de custódia da $26^{\mathrm{a}} \mathrm{DP}$, não permitindo que haja sequer tentativa de fuga, sendo essa considerada a mais segura da Polícia Civil, graças a seus desempenhos" (art. $1^{\circ}$, inciso XLI, Decreto ${ }^{\circ}$ 22.973/1997).

54 "Por terem, com o risco de suas próprias vidas, resgatado do fundo do mar um banhista que apresentava parada cardíaca e, prontamente, adotado os procedimentos técnicos adequados, persistindo no atendimento de primeiros socorros, até que os sinais vitais fossem restabelecidos" (art. $1^{\circ}$, inciso III, Decreto $n^{\circ} 22.317 / 1996$ ).

55 "Por terem evitado uma possível tragédia, decorrente de vazamento de gás no interior de um edifício, demonstrando profissionalismo e perícia" (art. $1^{\circ}$, inciso VIII, Decreto n ${ }^{\circ} 23.576-\mathrm{B} / 1997$ ).
} 
Com efeito, também houve acirramento entre as polícias, pois muitos policiais foram premiados em razão de flagrantes de ilícitos perpetrados por seus colegas de instituição. ${ }^{56}$ Como a dinâmica do sistema de premiação privilegiava quem estava lidando diretamente com os problemas na rua, logo houve acomodações e engenharias àqueles servidores cuja dinâmica de trabalho não fosse operacional, mas interna, burocrática, administrativa, também pudessem gozar desses benefícios e, assim, houve premiação à diretor de apoio logístico ${ }^{57}$, responsável pela informática ${ }^{58}$, mecânico de viaturas ${ }^{59}$, perito que emitisse algum laudo em caso de grande repercussão ${ }^{60}$, ou o colaborador da organização de um evento da corporação. ${ }^{61}$

A solidariedade ${ }^{62}$ - como socorrer vítima de atropelamento acompanhando-a ao hospital ${ }^{63}$, ou o socorro a um ciclista que se acidentasse ${ }^{64}$ - se exercitada pelo policial ou bombeiro, fora do expediente, também recebia prêmio. Igualmente reconhecido pelo Chefe do Poder Executivo como Mérito Especial, digno de premiação em pecúnia, foi a ação de

\footnotetext{
56 "Por ter demonstrado coragem, capacidade de decisão e elevado grau de formação moral ao prender, em flagrante delito, policiais militares que transportavam, no interior da viatura policial, gêneros alimentícios, armamento de procedência duvidosa e material entorpecente" (art. $1^{\circ}$, inciso V, Decreto $\mathrm{n}^{\circ}$ 22.930/1996). "Por ter demonstrado elevado grau de profissionalismo e destemor no cumprimento do dever funcional, quando participou de operação desencadeada após denúncia anônima e que culminou com a prisão de policial civil, em flagrante delito, por estar de posse de dois veículos roubados" (art. $1^{\circ}$, inciso XI, Decreto n $\left.{ }^{\circ} 22.930 / 1997\right)$. "Por ter impedido que marginais da lei, travestidos de policiais militares, resgatassem traficante de tóxico que se encontrava internado num nosocômio" (art. $1^{\circ}$, inciso III, Decreto no 23.092/1997). "Pelos excelentes resultados obtidos ao participarem das investigações que culminaram com a prisão de policiais pela prática de crimes de extorsão e homicídio" (art. $1^{\circ}$, inciso IV, Decreto $\left.\mathrm{n}^{\circ} 24.174 / 1998\right)$.

57 "Por ter se destacado de forma ímpar no desempenho das funções que atualmente exerce como Diretor Geral de Apoio Logístico da Polícia Militar, demonstrando ser um excelente administrador, onde através de competência, capacidade laborativa e criatividade, vem produzindo expressivos resultados que enaltecem a Corporação" (art. $1^{\circ}$, inciso II, Decreto $\mathrm{n}^{\circ} 22.822 / 1996$ ).

58 "Por haver se destacado no desenvolvimento de suas atividades administrativas na área de informática, tanto no Centro de Processamento de Dados da Polícia Militar, quanto na Assessoria de Comunicações e Informática da Secretaria de Segurança Pública, demonstrando responsabilidade, dedicação e competência" (art. º $^{\circ}$ inciso XXVI, Decreto $n^{\circ} 22.822 / 1996$ ).

59 "Por ter demonstrado alto grau de profissionalismo, dedicação e competência, destacando-se no desempenho das funções que vem exercendo como mecânico da Subseção de Manutenção e Transportes do $9^{\circ}$ GBM, não medindo esforços para a conservação das viaturas operacionais e administrativas daquela unidade" (art. $1^{\circ}$, inciso XXVIII, Decreto $\left.n^{\circ} 22.822 / 1996\right)$.

60 "Por ter elaborado laudo pericial, que culminou com a condenação de uma fraudadora do INSS, demonstrando alto grau de profissionalismo" (art. $1^{\circ}$, inciso XI, Decreto n $\left.{ }^{\circ} 24.008 / 1998\right)$.

61 "Por ter colaborado efetivamente na execução, com grande êxito, do evento realizado em comemoração aos 141 anos do CBMERJ" (art. $1^{\circ}$, inciso XIII, Decreto n ${ }^{\circ} 24.396 / 1998$ ).

62 "Por ter, quando de folga, agido com competência ao resgatar vítimas, demonstrando solidariedade humana" (art. $1^{\circ}$, inciso IV, Decreto $\left.n^{\circ} 23.157 / 1997\right)$.

63 "Por ter, quando da folga, atuado de forma eficiente num atropelamento prestando, no local, os primeiros socorros à vítima e acompanhando-a até o recebimento de atendimento médico adequado" (art. $1^{\circ}$, inciso XVIII, Decreto $\mathrm{n}^{\circ}$ 22.954/1997). "Por não ter medido esforços ao socorrer vítima de atropelamento, salvando-lhe a vida" (art. $1^{\circ}$, inciso XLIX, Decreto $\mathrm{n}^{\circ}$ 22.973/1997). "Por ter, quando de folga, com despojamento e bravura, prestado socorro à vítima de atropelamento" (art. $1^{\circ}$, inciso LIII, Decreto no $22.973 / 1997$ ).

64 "Por ter demonstrado responsabilidade e dedicação, quando de folga, prestou socorro a uma vítima de acidente de bicicleta" (art. $1^{\circ}$, inciso VI, Decreto $\mathrm{n}^{\circ}$ 23.674/1997).
} 
profissionais em convencer turista a não se suicidar em pleno cartão postal da cidade ${ }^{65}$; o resgate a grupo perdido dentro de um parque urbano ${ }^{66}$; ou, ainda, a participação em resgate de répteis mantidos em cativeiro. ${ }^{67}$

O controle de resultados experimentado nesse período não pode assim ser considerado, pois o que ocorreu, na verdade, foi uma política estratégica de governança, alinhada a opções políticas, de incentivo à ação repressiva e ostensiva dos policiais, com generosas concessões pecuniárias em seus vencimentos.

Ocorre que essa opção não seria sustentável para a Administração Pública por muito tempo, tendo em vista as repercussões nas contas públicas, posto que os servidores premiados incorporavam tal benefício proporcionalmente, e, da mesma forma, politicamente os efeitos de distorções salariais nas hierarquias policiais e a escalada da violência e da letalidade policial não escapariam dos controles social e parlamentar, por esse motivo que o Decreto $\mathrm{n}^{\mathbf{o}}$ 21.753/1995 que concedeu premiação por pecúnia, por mérito especial, foi objeto de reiteradas revogações:

i) a Lei estadual $\mathrm{n}^{\circ} 2.993$, de 30 de junho de 1998, determinou a edição de lei para especificar e detalhar os critérios para a concessão de promoção ou de adicional de remuneração a qualquer título, de modo a que os atos concessivos de promoção ou remuneração em pecúnia para funcionários públicos civis ou militares que fossem resultados de atos meritórios só poderiam ocorrer por decisão do Poder Executivo de acordo com o disposto em lei, de cuja iniciativa legislativa caberia ao Governador, além disso, revogou expressamente o Decreto $\mathrm{n}^{\circ}$ 21.753/1995;

ii) o Decreto $n^{\circ}$ 25.641/1999 dispôs sobre a concessão de gratificação aos policiais civis e militares integrantes das organizações policiais que apresentassem redução de indicadores de criminalidade ou padrões de eficiência operacional ou administrativa. Por disciplinar a matéria de outro modo, revogou-se tacitamente as disposições em contrário previstas no Decreto no 21.753/1995;

iii) não obstante a revogação expressa na Lei estadual no 2.993/1998, de iniciativa de Deputado Estadual, expressão do controle parlamentar sobre os atos da Administração

\footnotetext{
65 "Por terem demonstrado coragem e profissionalismo, ao impedirem após quase cinco horas de conversação, através de técnicas de persuasão, que um cidadão americano se suicidasse, se jogando do alto do Morro do Pão de Açúcar" (art. $1^{\circ}$, inciso XXXII, Decreto n 22.561/1996).

66 "Pelos excelentes resultados obtidos ao participarem do resgate de um grupo de pessoas que se encontrava perdido no Parque Nacional da Tijuca" (art. $1^{\circ}$, inciso IX, Decreto $n^{\circ} 23.674 / 1997$ ).

67 "Por terem demonstrado alto preparo profissional ao participarem, com êxito, do resgate de vários répteis que se encontravam mantidos em cativeiro" (art. $1^{\circ}$, inciso XXI, Decreto $n^{\circ}$ 24.396/1998).
} 
Pública, além da revogação tácita operada pelo Decreto nº 25.641/1999, que disciplinou de outra forma a matéria, o Governador Anthony Garotinho editou o Decreto n 26.249/2000 para expressamente constar que ficava "revogado o Decreto $\mathrm{n}^{\circ} 21.753$, de 8 de novembro de 1995 , que concede premiação em pecúnia, por mérito especial [...]”.

A controvérsia não ficou circunscrita aos ambientes administrativo, parlamentar e social, pois a "gratificação faroeste" gerou discussões jurídicas sobre a legalidade da sua supressão e a interrupção do seu pagamento aos milhares de policiais e bombeiros, em decorrência da sua revogação, tendo o Tribunal de Justiça do Estado do Rio de Janeiro se manifestado pacificamente pela natureza pro labore, pessoal, individualizada e específica, não podendo ser suprimida por ato genérico e de alcance indiscriminado da Administração. ${ }^{68}$

Vislumbra-se, pois, que essa experiência da Administração Pública não foi a instituição de uma modalidade de controle de resultados sobre o serviço público prestado pelo setor da segurança pública. A dinâmica prevista pelo Decreto ${ }^{\circ}$ 21.753/1995 reduziu-se à política de governo de gratificação pecuniária, sem critérios para se aferir eficiência e produção a partir de parâmetros. Os atos de bravura, que inicialmente valorizariam o ethos guerreiro do policial, foi banalizado, virou moeda de troca, entrou no vale tudo da política, e perdeu a dignidade que lhe seria distintiva, passando ao largo, reitere-se, de um controle efetivo de resultados sobre a atuação da Administração na segurança pública.

\subsection{Gratificação aos policiais cujas organizações apresentassem redução de indicadores de criminalidade ou padrões de eficiência operacional ou administrativa}

Decreto n 25.641, de 19 de outubro de 1999, editado para substituir a "gratificação faroeste", dispôs sobre a concessão de gratificação aos policiais civis e militares integrantes das organizações policiais que apresentassem redução de indicadores de criminalidade ou padrões de eficiência operacional ou administrativa. Foi motivado no artigo 144 da Constituição da República e no artigo 183 da Constituição do Estado do Rio de Janeiro, dispositivos constitucionais que preconizam ser dever do Estado prover os serviços de segurança pública para a preservação da ordem pública e da incolumidade das pessoas e do patrimônio, além de

\footnotetext{
${ }^{68}$ TJRJ, Órgão Especial, Mandado de Segurança no 2002.004.01023, Rel. Des. Miguel Pachá, j. 12.2.2001.

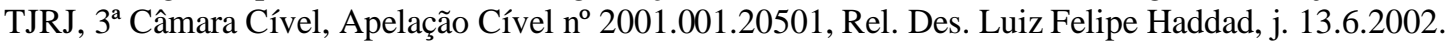


considerar na motivação expressamente o princípio da eficiência que à época da edição do decreto era recém introduzido no caput do artigo 37 da Constituição de 1988.

Cuidou o referido ato normativo apenas dos policiais civis e militares, não considerando os bombeiros militares, pois objetivou que as Áreas Integradas de Segurança Pública, às quais os policiais estariam circunscritos, apresentassem redução de indicadores de criminalidade e padrões de eficiência, de modo a que, com isso, fariam jus, no mês de apuração, a uma gratificação de até $\mathrm{R} \$ 500,00$ (quinhentos reais), valor igual para todos os beneficiários, fixado de acordo com as disponibilidades financeiras do Administração, não se incorporando, para quaisquer efeitos, aos vencimentos do servidor.

Ademais, o próprio Decreto positivou o que significaria, para todos os efeitos, os parâmetros para a concessão da gratificação. Dessa maneira, considerou como indicadores de criminalidade um conjunto de variáveis objetivas, de natureza criminal ou não, que repercutissem, direta ou indiretamente, na segurança pública, definidas a partir dos registros de ocorrências policiais e de outras fontes válidas de aferição; por outro lado, padrões de eficiência administrativa elou operacional seria um conjunto de iniciativas gerenciais orientadas para a melhoria contínua da administração dos serviços policiais e do desenvolvimento de estratégias diferenciadas de prevenção e repressão qualificada da criminalidade.

A cada mês o Governador concedia gratificação aos policiais integrantes de três Áreas Integradas de Segurança Pública, sendo uma de cada Região, a partir das indicações feitas pelo Secretário de Estado de Segurança com base no Relatório de Avaliação apresentado por um Grupo Executivo das Áreas Integradas de Segurança Pública. Não obstante, as organizações policiais não integrantes de Áreas Integradas poderiam, quando apresentassem padrões de eficiência, ser indicadas, mediante exposição fundamentada, pelo Comandante-Geral ou Chefe de Polícia Civil para fins de concessão da gratificação.

Com o intuito de corrigir os rumos que haviam sido tomados com a "gratificação faroeste", o Decreto $\mathrm{n}^{\circ}$ 25.641/1999 expressamente fez constar que policiais civis e militares que estivessem cumprindo sanção penal ou administrativa ou respondendo a processo criminal, fosse comum ou militar, ou inquérito policial ou inquérito policial militar, processo administrativo disciplinar ou outro procedimento investigativo "decorrente de imputação de desvio de conduta de qualquer natureza", somente receberiam a gratificação após decisão final que lhes fosse favorável, ficando sobrestado o pagamento da premiação.

Ocorre que essa dinâmica de controle dos índices de criminalidade e dos padrões de eficiência não foi institucionalizada e operacionalizada de modo contínuo, a se fortalecer 
como um controle institucionalizado de resultados da Administração, por diversos elementos: houve uma ruptura brusca com a política anterior fazendo com que houvesse uma reacomodação dos policiais, que antes agiam livremente e no atuar de suas atividades ordinárias conseguiam dobrar ou triplicar os vencimentos no contracheque, porém, como já mencionado, essa política não seria sustentável por muito tempo e a crise financeira no governo seguinte logo obrigou a interromper o pagamento das gratificações na forma como estavam sendo concedidas.

O valor fixo oferecido como compensação, não incorporando, provavelmente desestimulou os policiais que voltaram para as suas dinâmicas de complementação de renda. Além disso, o cenário político-eleitoral agitado também contribuía para que o sistema estruturado pelo referido Decreto não se firmasse, bem como a pasta da Segurança Pública passava a atuar em outras frentes, com outros projetos e respectivas gratificações (como o Programa Delegacia Legal e as gratificações no valor de R \$ 500,00 aos policiais lotados nas novas delegacias informatizadas; a criação da Gratificação Especial de Atividade - GEAT, que não incorporava aos vencimentos e variava de $\mathrm{R} \$ 100,00$ a $\mathrm{R} \$ 500,00$ a depender do posto/classe do policial).

Essa gratificação, a partir de redução de indicadores de criminalidade ou padrões de eficiência operacional ou administrativa, foi concebida para minimamente conseguir aferir e medir a produtividade e, por conseguinte, os resultados. Porém, por falta de condições orçamentárias, crise político-eleitoral, problemas de gestão na condução da política de segurança pública e, sobretudo, falta de envolvimento dos policiais, não vingou. Não se conseguiu estruturar e institucionalizar um controle de resultados na segurança. Atuou-se em outras frentes políticas importantes, como o Programa Delegacia Legal, e se fixou em gratificações com valor máximo de $\mathrm{R}$ \$ 500,00, não havendo, assim, condições para efetivação de controle sobre a produtividade do serviço de redução da criminalidade, tampouco de padrões de eficiência.

\subsection{Sistema de Definição e Gerenciamento de Metas para os indicadores estratégicos de criminalidade do Estado do Rio de Janeiro}

Em 25 de junho de 2009, o Governador Sérgio Cabral editou o Decreto nº 41.931, dispondo sobre o sistema de definição e gerenciamento de metas para os indicadores 
estratégicos de criminalidade do Estado do Rio de Janeiro, tendo como motivação instituir um sistema de acompanhamento de metas que demandasse dos profissionais de segurança pública "o imprescindível trabalho integrado para busca de resultados comuns, pautado no preciso entendimento do comportamento do fenômeno criminal em suas áreas de responsabilidade e a consequente adoção de ações conjuntas, adequadas e inteligentes", acreditando-se que tal sistema propiciaria "uma avaliação adequada da qualidade do desempenho de seus profissionais de polícia e outros agentes de segurança pública envolvidos, com o consequente reconhecimento de boas práticas, ações e resultados" permitindo, assim, "um adequado reconhecimento do mérito".

Entendeu-se por meta, para fins de aplicação do sistema de gerenciamento implantado, o resultado esperado com relação a diversos indicadores estratégicos de criminalidade, sendo as metas estabelecidas levando-se em consideração a realidade distinta existente entre as localidades objeto de sua aplicação.

Além disso, indicadores estratégicos de criminalidade foram organizados por grupos de tipos penais que impactam mais fortemente na sensação de (in)segurança, a saber: i) letalidade violenta, compreendendo homicídio doloso, autos de resistência, latrocínio e lesão corporal seguida de morte; ii) roubo de veículos; iii) roubos de rua, abrangendo as categorias de roubo a transeuntes, roubos em coletivos e roubos de celulares.

Uma Comissão de Acompanhamento e Avaliação do sistema de definição e gerenciamento de metas foi instituída e composta só por autoridades condutoras da política de segurança e finanças do Estado e gestores das instituições policiais, não havendo representação das diversas categorias de policiais que operacionalizam a segurança. Sobreleva-se que as metas foram estabelecidas por meio de contratos de gestão envolvendo tais autoridades, contemplando a assunção de compromisso de cumprimento das metas e de concordância com os critérios e valores de premiação.

Com efeito, sobressai a utilização, dentro do Sistema de Definição e Gerenciamento de Metas na área da segurança pública, do instrumento de contrato de gestão, previsto na Constituição da República (art. 37, $\S 8^{\circ}$ ) que, segundo Gustavo Justino de Oliv eira, realçou a importância de serem estabelecidos mecanismos de controle de gestão voltados à avaliação do desempenho e dos resultados alcançados pela máquina administrativa ${ }^{69}$, cumprindo observar que não se trata de um instituto contratual administrativo, mas um "recurso de índole consensual

\footnotetext{
${ }^{69}$ OLIVEIRA, Gustavo Justino de. Contrato de gestão. São Paulo: RT, 2008, p. 184.
} 
a ser aplicado no campo das relações administrativas", com vocação para incrementar o desempenho dos órgãos e entidades a partir de uma autonomia de gestão, com programação prévia de suas atividades e mecanismos de controle de resultados aferidos. ${ }^{70}$

Inicialmente o sistema foi estruturado para fixação de metas gerais e específicas anuais, levando-se em consideração a série histórica do indicador criminal nos últimos quatro anos e as tendências previstas do indicador para o ano seguinte. Os resultados seriam apurados mensalmente, transformados em pontos, mas a periodicidade da premiação aos policiais seria anual.

Ocorre que em poucos meses essa dinâmica foi ajustada "no que tange à periodicidade de sua avaliação, de forma a aperfeiçoá-lo e motivar os profissionais que serão avaliados", conforme motivação do Decreto n ${ }^{\circ} 42.243 / 2010$ que instituiu o ciclo de seis meses, com metas semestrais e premiações aos policiais a cada ciclo semestral. Com a preocupação de não ser conivente e premiar maus policiais, previu o sistema que não fariam jus à premiação os servidores afastados do serviço em decorrência de aplicação de sanção criminal ou disciplinar, ou por conta de prisão ou afastamento cautelar determinado no âmbito de processo judicial ou administrativo.

A premiação por produtividade aos policiais operava-se por Gratificação de Encargos Especiais pagas em única vez a cada ciclo de seis meses e não cumulativa. Além disso, observando a experiência desastrosa da "gratificação faroeste", o ato normativo que instituiu esse Sistema de Metas previu expressamente que as premiações não integrariam a base de cálculo de contribuição previdenciária "e, por seu caráter pro labore faciendo" não se incorporariam aos proventos de inatividade, nem seriam devidas a inativos e pensionistas.

Verifica-se que o sistema instituído foi constantemente ajustado para aperfeiçoamento da metodologia de cálculo do grau de produtividade ${ }^{71}$, extensão da premiação

\footnotetext{
${ }^{70}$ Ibid., p. 238.

71 “Os resultados apurados a cada ciclo semestral pelas RISP - Região Integrada de Segurança Pública e AISP Áreas Integradas de Segurança Pública serão transformados em Índice de Desempenho de Metas - IDM. O Índice de Desempenho de Metas - IDM é calculado a partir do resultado do percentual de cumprimento de meta de cada um dos Indicadores Estratégicos de Criminalidade, monitorados pelo Sistema de Metas. O Percentual de Cumprimento da Meta representa a diferença entre a meta e o realizado, para o indicador no período [.... O Índice de Desempenho de Metas - IDM corresponde ao somatório dos fatores alcançados para cada um dos Indicadores Estratégicos de Criminalidade [...] Os Índices de Desempenho de Metas - IDM calculados servirão para o estabelecimento de um Ranking de premiados que permitirá avaliar, o desempenho das RISP e AISP, tendo como condição, para esta modalidade específica, que o Percentual de Cumprimento da Meta de cada um dos Indicadores Estratégicos tenha sido igual ou acima de $100 \%$ [...]. Serão objetos de premiação semestral: a RISP que totalizar o melhor resultado no Índice de Desempenho de Metas - IDM, desde que tenha cumprido integralmente todas as metas semestrais estabelecidas; as 03 (três) AISP que totalizarem os três melhores resultados no Índice de Desempenho de Metas - IDM, desde que tenham cumprido integralmente todas as metas semestrais estabelecidas;
} 
às mais distintas unidades administrativas e operacionais cujo trabalho contribuísse para a produção de resultados em relação aos indicadores de criminalidade selecionados ${ }^{72}$, bem como, buscando "manter ainda mais motivados os servidores", como consta da motivação do ato normativo, o Governador Sérgio Cabral constantemente majorava os valores atribuídos à gratificação semestral e individual dos policiais que atingissem as metas. ${ }^{73}$

O sistema de metas, objetivando reduzir determinados indicadores de criminalidade que impactavam na sensação de (in)segurança da população, foi estruturado de maneira sofisticada, utilizando-se de metodologias quantitativas e de instrumentos jurídicoadministrativos de uma nova forma de governança da Administração Pública, como é o caso dos contratos de gestão utilizados, porém não existe sistema perfeito, imune a manipulações e fraudes. Embora tenha sido ajustado e acompanhado constantemente, o alcance foi muito limitado, pois as gratificações como premiação por produtividade não estavam ao alcance da maioria dos policiais, só um número reduzido conseguia ocupar os primeiros lugares nos rankings estabelecidos.

Não obstante a estruturação empreendida, qualificada e sofisticada em relação às experiências anteriores, ela focalizava na gratificação como um atrativo compensador, uma motivação, para fazer com que os servidores policiais se alinhassem à política de governo na área da segurança pública, notadamente a redução de determinados crimes, por isso visava criar competitividade, estabelecendo ranking em que unidades, áreas e regiões disputassem quais conseguissem os melhores resultados, ou seja, superar as metas estabelecidas pelos gestores da cúpula da segurança.

Porém, cabe indagar se esse Sistema de Metas seria um sofisticado programa de gratificação extraordinária aos policiais (em troca de atingir metas) ou se configuraria como um

as RISP e AISP que atingirem o Índice de Desempenho de Metas - IDM, a partir do limite mínimo de $90 \%$ e máximo de $120 \%$ do estabelecido, desde que cumpridas as condições instituídas neste Decreto; as 3 (três) melhores iniciativas de Unidades Policiais Especializadas da Polícia Civil e Unidades Operacionais Especiais da Polícia Militar do Estado do Rio de Janeiro, por corporação, no controle da criminalidade, a serem escolhidas pela Comissão de Acompanhamento e Avaliação; o cumprimento pelo SARPM/COINPOL/PCERJ [Serviço de Análises de Rotinas Policiais e Monitoramento da Corregedoria Interna da Polícia Civil do Estado do Rio de Janeiro] e pelo NUPESP/ISP [Núcleo de Pesquisa em Justiça Criminal e Segurança Pública do Instituto de Segurança Pública] de suas atribuições previstas no inciso V do art. $6^{\circ}$ deste Decreto [cumprir as atribuições com antecedência mínima de 24 horas do prazo limite estabelecido, e de forma ininterrupta, durante o período do ciclo de avaliação tendo em vista a necessidade de divulgação célere e fidedigna dos dados oficiais desses indicadores]". Cf. Decreto n ${ }^{\circ} 41.931 / 2009$ com redação dada pelos Decretos no 43.055/2011, no 43.989/2012 e no 44.137/2013.

${ }^{72}$ Foram premiados servidores lotados em atividades administrativas, unidades operacionais e especializadas, desde que fossem observados os indicadores de produtividade e o alcance das metas estipuladas.

${ }^{73}$ Inicialmente, em 2009, quando da estruturação do Sistema de Metas, os valores das gratificações que eram anuais variavam de R \$ 500,00 à R \$ 1.500,00. Após majorações, em 2013, os valores das gratificações semestrais passaram a variar de no mínimo $\mathrm{R} \$ 1.500,00$ até $\mathrm{R} \$ 13.500,00$, conforme Decreto n ${ }^{\circ}$ 44.348/2013. 
controle de resultados da Administração Pública. Para os que atingiam as metas e, com isso, demonstravam produtividade e resultados aos olhos da cúpula da gestão da segurança, o resultado era a participação em solenidade com as autoridades e cobertura midiática, com placas, diplomas e gratificação individual no contracheque.

Todavia, e àqueles que não alcançavam as metas estabelecidas? Fosse pelos motivos mais diversos como falta de condições institucionais, materiais, recursos humanos, (des)interesse profissional, quais seriam as consequências administrativo-disciplinar e jurisdicional? Há quem defenda o manejo da ação civil pública para, em casos como esse, se postular em juízo que a Administração Pública preste o serviço de forma eficiente e apresente bons resultados, mas quais resultados seriam esses e qual o alcance do Poder Judiciário nessa área? Os bons resultados seriam as metas estabelecidas pelos órgãos de governo?

Decerto que a questão passa pelo crivo da conveniência da governança da Administração Pública pelo Chefe do Poder Executivo que, embora possua margem ampla para atuação, deve prestar um serviço público de maneira eficiente e com resultados satisfatórios e o seu controle é tema desafiador.

Geralmente o gestor sopesa os custos políticos, sociais e orçamentários para adotar alguma medida nesta área que tem reduzido o controle de resultados e de eficiência a programas de incentivo de determinados grupos de servidores com gratificações que, todavia, são insuficientes para gerar produtividade em escala para alteração da realidade.

\section{Conclusão}

Observa Cláudio Pereira de Souza Neto que apesar de passados mais de vinte anos do fim do regime militar, as políticas de segurança pública ainda são concebidas como estratégia de guerra e não se submetem ao programa democrático constitucionalmente estabelecido, de modo que apenas políticas alicerçadas em concepções democráticas são compatíveis com a Constituição de 1988 e a segurança pública deve ser compreendida como um serviço público a ser universalizado de maneira igual, tendo em vista estar programado no artigo 144 ser dever do Estado e direito e responsabilidade de todos. ${ }^{74}$

\footnotetext{
${ }^{74}$ SOUZA NETO, Cláudio Pereira de. Constitucionalismo democrático e governo das razões: estudos de direito constitucional contemporâneo. Rio de Janeiro: Lumen Juris, 2010, p. 274-280.
} 
Há carência de políticas públicas na área da segurança pública que possa funcionar como modelo de orientação para decisões articuladas, desencadeando, como ressalta Luiz Eduardo Soares, conjunto sistemático de ações a serem empreendidas pelas polícias e por outras agências ligadas à estrutura administrativa da segurança, sendo, pois, responsáveis por "fazer as peças funcionarem de modo a cumprirem suas finalidades e as metas derivadas". ${ }^{75}$

No mesmo sentido, Maria Paula Dallari Bucci acentua que as políticas públicas, de modo geral, devem visar a "realização de objetivos definidos, expressando a seleção de prioridades, a reserva de meios necessários à sua consecução e o intervalo de tempo em que se espera o atingimento dos resultados". ${ }^{76}$ Além disso, as políticas públicas contrastam com as estruturas estatais que apenas repetem rotinas administrativas e produzem atos concretos, pois delas se diferenciam ao se caracterizarem como programas de ação governamental. Por este ângulo, a referida autora destaca que o núcleo de sentido da política pública reside na ação governamental como expressão de movimento que se dá à máquina pública, conjugando competências, objetivos e meios estatais a partir do governo, já a apresentação exterior da política pública materializa-se em arranjo institucional que se caracteriza como conjunto de iniciativas e medidas articulado por suportes e formas jurídicas diversas - leis, decretos, resoluções, deliberações, portarias, regulamentos, são alguns exemplos de qualificação jurídica das decisões políticas. ${ }^{77}$

Além da carência de políticas públicas, ainda quando algum programa de governo é implementado, há falhas na avaliação e isso repercute no controle de resultados. Claudio Beato adverte que a escassez de avaliações - de processos, de resultados e de custo/benefício têm "circunscrito o debate sobre a segurança pública num universo retórico e eivado de preconceito e prenoções", de modo que "estamos frequentemente propondo soluções às cegas". 78

Especialistas alertam para déficit de estudos de avaliação em políticas de segurança pública e prática de avaliação ainda incipiente, seja em decorrência de cultura institucional, seja por falta de clareza na definição de critérios objetivos que sirvam para medir os resultados e respectivo impacto. Observam, igualmente, alguns fatores para essa ausência de avaliações de

\footnotetext{
75 SOARES, Luiz Eduardo. Política de segurança pública. In: DI GIOVANNI, Geraldo; NOGUEIRA, Marco Aurélio (Orgs.). Dicionário de políticas públicas. 2. ed. São Paulo: Unesp; Fundap, 2015, p. 739-740.

${ }^{76}$ BUCCI, Maria Paula Dallari. O conceito de política pública em direito. In: BUCCI, Maria Paula Dallari (org.).

Políticas públicas: reflexões sobre o conceito jurídico. São Paulo: Saraiva, 2006, p. 39.

${ }^{77}$ Idem. Fundamentos para uma teoria jurídica das políticas públicas. São Paulo: Saraiva, 2013, p. 38-39.

${ }^{78}$ BEATO FILHO, Cláudio Chaves. Crime e cidades. Belo Horizonte: Editora UFMG, 2012, p. 131-132.
} 
impacto na segurança pública: existência de efeitos a médio e longo prazos; limitações de fontes, notadamente o sub-registro das ocorrências policiais; bem como o deslocamento da atividade criminal de uma área de intervenção para outras localidades. ${ }^{79}$

As dificuldades de se aferir a eficiência na prestação do serviço de segurança pública sobressaem tanto quando se analisa o tema sob o enfoque teórico-doutrinário quanto sob o enfoque da realidade prática da Administração Pública, confirmando assertiva de Luiz Eduardo Soares: "a avaliação do desempenho policial talvez seja uma das funções mais desafiadoras e complexas de todas as que existem na segurança pública". ${ }^{80}$

Sobre o controle de resultados especificamente, Luiz Carlos Bresser-Pereira frisa que não se pode confundir controle de resultados com permanente definição e redefinição dos processos de trabalho, que deve ser estratégia gerencial por excelência, com controle de procedimentos, caracterizador da administração burocrática. Não bastando, todavia, a gestão nos resultados, sendo esta importante, mas não suficiente, requerendo-se a compreensão sobre os processos formais e informais pelos quais os resultados são produzidos, sendo necessárias capacidade e condições para monitorar e ajustar esses processos.

Adverte ainda Bresser-Pereira, com base em W. Edward Deming, ser inaceitável a definição de objetivos ou de resultados para um trabalhador, um departamento, ou uma empresa, sem que a administração tenha definido com clareza quais as melhorias nos processos que permitirão alcançar esse objetivo, sendo, pois, fundamental a participação, em cada nível, dos próprios trabalhadores que executam a tarefa, tendo em vista "a importância da participação dos trabalhadores na definição do processo de trabalho, como forma de motivação". ${ }^{81}$

Muito ainda se tem a construir para institucionalização de um controle de resultados que promova a eficiência e valorize o trabalho dos policiais, qualificando o serviço público prestado pela Administração. Atualmente, esse controle não é exercido, seja por não estar suficientemente estruturado, seja pela rejeição dos próprios policiais a se vincularem a políticas de governo que os controlem, sem valorizá-los.

A situação faz recordar sermão de Padre Antônio Vieira, em 13 de junho de 1654 em São Luís do Maranhão: “o efeito do sal é impedir a corrupção, mas quando a terra se vê tão

\footnotetext{
${ }^{79}$ LOCHE, Adriana; CARBONARI, Flavia; HOFFMAN, Joan Serra; SERRANO-BERTHET, Rodrigo. Avaliação de políticas em segurança pública. In: LIMA, Renato Sérgio de; RATTON, José Luiz; AZEVEDO, Rodrigo Ghiringhelli de (Orgs.). Crime, polícia e justiça no Brasil. São Paulo: Contexto, 2014, p. 613.

${ }^{80}$ SOARES, Luiz Eduardo. Meu casado de general: quinhentos dias no front da segurança pública do Rio de Janeiro. São Paulo: Companhia das Letras, 2000, p. 367.

${ }^{81}$ BRESSER-PEREIRA, Luiz Carlos. Reforma do Estado para a cidadania: a reforma gerencial brasileira na perspectiva internacional. 2. ed. São Paulo: Ed. 34; Brasília: ENAP, 2011, p. 147-148.
} 
corrupta como está a nossa, qual pode ser a causa dessa corrupção? Ou é porque o sal não salga, ou porque a terra se não deixa salgar". Ademais, o sal tem duas propriedades, "conservar o são e preservá-lo para que se não corrompa”. Pregando em referência a Santo Antônio para os peixes, lembrou o Padre português que Aristóteles, falando dos peixes, “diz que só eles, entre todos os animais, se não domam nem domesticam". 82

Assim tem sido os paradoxos desafiadores envolvendo o controle de resultados sobre a Administração Pública brasileira; ou o controle não controla ou a Administração não se deixa controlar. E, nessa alusão, os peixes seriam os policiais, de difícil domínio e domesticação, se comparado com o restante dos quadros do funcionalismo. É tempo de pregação e de produção, que faça avançar o conhecimento nesta área, mas, sobretudo, de realização de obras que operem na realidade para concretização dos direitos fundamentais e da preservação da ordem pública democrática e da incolumidade das pessoas e do patrimônio. Há muito o que construir ainda para aperfeiçoamento da Administração Pública brasileira voltada para os resultados na segurança pública.

\section{Referências}

BATISTA, Nilo. Prefácio. In: OLIVEIRA, Siro Darlan de; ROMÃO, Luis Fernando de França. A história da criança por seu conselho de direitos. Rio de Janeiro: Revan, 2015.

BEATO FILHO, Claudio Chaves. Crime e cidades. Belo Horizonte: Editora UFMG, 2012.

BELTRAME, José Mariano. Todo dia é segunda-feira. Rio de Janeiro: Sextante, 2014.

BRESSER-PEREIRA, Luiz Carlos. Reforma do Estado para a cidadania: a reforma gerencial brasileira na perspectiva internacional. 2. ed. São Paulo: Ed. 34; Brasília: ENAP, 2011.

BUCCI, Maria Paula Dallari. O conceito de política pública em direito. In: BUCCI, Maria Paula Dallari (Org.). Políticas públicas: reflexões sobre o conceito jurídico. São Paulo: Saraiva, 2006.

BUCCI, Maria Paula Dallari. Fundamentos para uma teoria jurídica das políticas públicas. São Paulo: Saraiva, 2013.

CARVALHO, Luiz Maklouf. Crime \& Castigo. O caçador de milícias. PIAUÍ, 27. ed., dez. 2008. Disponível em: <https://piaui.folha.uol.com.br/materia/o-cacador-de-milicias/>. Acesso em: 08 mar. 2021.

\footnotetext{
82 VIEIRA, Padre Antônio. Sermão de Santo Antônio. Disponível em: <http://www.dominiopublico.gov.br/download/texto/bv000033.pdf>. Acesso em: 13 mar. 2021.
} 
DA SILVA, Jorge. Controle da criminalidade e segurança pública na nova ordem constitucional. 2 ed. Rio de Janeiro: Forense, 1990.

HOLLANDA, Cristina Buarque de. Polícia e direitos humanos: política de segurança pública no primeiro governo Brizola (Rio de Janeiro: 1983-1986). Rio de Janeiro: Revan, 2005.

IANNOTTA, Lucio. Merito, discrezionalità e risultato nelle decisioni amministrative (l'arte di amministrare). Diritto processuale amministrativo, v. 23, fasc. 1, p. 1-51, 2005.

LOCHE, Adriana; CARBONARI, Flavia; HOFFMAN, Joan Serra; SERRANO-BERTHET, Rodrigo. Avaliação de políticas em segurança pública. In: LIMA, Renato Sérgio de; RATTON, José Luiz; AZEVEDO, Rodrigo Ghiringhelli de (Orgs.). Crime, polícia e justiça no Brasil. São Paulo: Contexto, 2014.

MARQUES NETO, Floriano de Azevedo. Os grandes desafios do controle da Administração Pública. Fórum de Contratação e Gestão Pública - FCGP, Belo Horizonte, ano 9, n. 100, abr. 2010.

MEDAUAR, Odete. Controle da administração pública. 3. ed. São Paulo: RT, 2014.

MOREIRA NETO, Diogo de Figueiredo. Curso de direito administrativo: parte introdutória, parte geral e parte especial. 16. ed. Rio de Janeiro: Forense, 2014.

MOREIRA NETO, Diogo de Figueiredo. Novo referencial no Direito Administrativo: do controle da vontade ao do resultado: a juridicização dos resultados na Administração Pública. Fórum Administrativo - Direito Público - FA, Belo Horizonte, ano 6, n. 67, set. 2006.

OLIVEIRA, Gustavo Justino de. Contrato de gestão. São Paulo: RT, 2008.

PÉREZ, Elizabeth Martin. Meios de comunicação de massa e aparato policial: a ação da mídia em questões de segurança pública. Dissertação (Mestrado em Administração Pública) Escola Brasileira de Administração Pública e de Empresas, Fundação Getúlio Vargas. Rio de Janeiro, 2003.

ROMÃO, Luis Fernando de França. Sobre a proteção jurídica das políticas públicas do processo eleitoral: o caso da política de segurança pública no Estado do Rio de Janeiro. In: MENDES, Soraia Rosa; AGUIAR, Julio Cesar de (Orgs.). Segurança pública. Brasília: IDP, 2014.

SANTIN, Valter Foleto. Controle judicial da segurança pública: eficiência do serviço na prevenção e repressão ao crime. 2. ed. São Paulo: Verbatim, 2013.

SOARES, Luiz Eduardo. Legalidade libertária. Rio de Janeiro: Lumen Juris, 2006.

SOARES, Luiz Eduardo. Meu casado de general: quinhentos dias no front da segurança pública do Rio de Janeiro. São Paulo: Companhia das Letras, 2000. 
SOARES, Luiz Eduardo. O enigma de Nova York. In: OLIVEIRA, Nilson Vieira (Org.). Insegurança pública: reflexões sobre a criminalidade e a violência urbana. São Paulo: Nova Alexandria, 2002.

SOARES, Luiz Eduardo. Política de segurança pública. In: DI GIOVANNI, Geraldo; NOGUEIRA, Marco Aurélio (Orgs.). Dicionário de políticas públicas. 2. ed. São Paulo: Unesp; Fundap, 2015.

SOUZA NETO, Cláudio Pereira de. Constitucionalismo democrático e governo das razões: estudos de direito constitucional contemporâneo. Rio de Janeiro: Lumen Juris, 2010.

STORANI, Paulo. Vitória sobre a morte: a glória prometida. O "rito de passagem" na construção da identidade dos Operações Especiais. Dissertação (Mestrado em Antropologia Social), Programa de Pós-Graduação em Antropologia, Universidade Federal Fluminense. Niterói, 2008.

TÁCITO, Caio. O controle da Administração e a nova Constituição do Brasil. Revista de Direito Administrativo, Rio de Janeiro, v. 90, 1967.

VIEIRA, Padre António. Sermão de Santo Antônio. Disponível em: <http://www.dominiopublico.gov.br/download/texto/bv000033.pdf>. Acesso em: 13 mar. 2021.

Recebido em: 13/03/2021

$1^{\circ}$ parecer: $16 / 03 / 2021$

$2^{\circ}$ parecer: $26 / 03 / 2021$

$3^{\circ}$ parecer: 07/06/2021 